\title{
POZIOM ZAUFANIA I WIARYGODNOŚĆ POLSKICH STUDENTÓW NA TLE MIĘDZYNARODOWYM*
}

\section{WSTĘP}

Zaufanie uogólnione jest często przywoływanym aktualnie przedmiotem badań, z uwagi na jego powiązanie z kapitałem społecznym, który - jak się wskazuje - jest jednym z czynników wpływających na produktywność czynników wytwórczych i wzrost gospodarczy ${ }^{1}$. Jednocześnie badania pokazują ${ }^{2}$, że poziom zaufania oraz szerzej - kapitału społecznego Polaków - jest niski w porównaniu z innymi krajami i może mieć zwiąek z gorszymi efektami ekonomicznymi ${ }^{3}$, a nawet być barierą długookresowego wzrostu gospodarczego ${ }^{4}$.

Niektórzy badacze wskazuja, że analiza porównawcza kapitału społecznego Polski z innymi krajami w szerszym wymiarze uwzględniać powinna kon-

* Projekt został sfinansowany ze środków Narodowego Centrum Nauki przyznanych na podstawie decyzji numer DEC-2012/07/B/HS5/03954.

${ }^{1}$ R. E. Hall, C. I. Jones, Why do some countries produce so much more output per worker than others?, „The Quarterly Journal of Economics” 114(1), 1999, s. 83-116; S. Knack, P. Keefer, Does social capital have an economic payoff? A cross-country investigation, "The Quarterly Journal of Economics" 112(4), 1997, s. 1251-1288; P. J. Zak, S. Knack, Trust and growth, „The Economic Journal” 111(470), 2001, s. 295-321; J. Temple, P. A. Johnson, Social capability and economic growth, "The Quarterly Journal of Economics” 113(3), 1998, s. 965-990; P. F. Whiteley, Economic growth and social capital, „Political Studies” 48(3), 2000, s. 443-466; C. Bjørnskov, How does social trust affect economic growth?, „Southern Economic Journal” 78(4), 2012, s. 1346-1368; J. Dearmon, K. Grier, Trust and development, „Journal of Economic Behavior \& Organization" 71(2), 2009, s. 210-220; N. Berggren, M. Elinder, H. Jordahl, Trust and growth: a shaky relationship, „Empirical Economics” 35(2), 2008, s. 251-274.

2 C. Wallace, F. Pichler, Bridging and bonding social capital: which is more prevalent in Europe, „European Journal of Social Security” 9, 2007, s. 29.

${ }^{3}$ M. Paldam, G. T. Svendsen, Missing Social Capital and the Transition in Eastern Europe, Department of Economics, Faculty of Business Administration, Aarhus School of Business 2000; J. Fidrmuc, Mind the gap! Social capital, East and West, „Journal of Comparative Economics” 36(2), 2008, s. 264-286; M. Raiser et al., Social capital in transition: a first look at the evidence, „Sociologický Časopis / Czech Sociological Review” 38(6), 2002, s. 693-720; M. Młokosiewicz, Social capital in Poland compared to other member states - the analysis of the phenomenon at macrolevel, „Economics and Sociology” 2(1), 2009; D. Mihaylova, Social Capital in Central and Eastern Europe: A Critical Assessment and Litererature Review, Central European University, Budapest 2004.

${ }^{4}$ J. Czapiński, Kapitał ludzki i kapitał spoteczny a dobrobyt materialny. Polski paradoks, „Zarządzanie Publiczne” 2(4), 2008. 
tekst kulturowy i historyczny, a proste porównanie badań sondażowych budzi wątpliwości. W porównaniach międzynarodowych kapitał społeczny bardzo często mierzony jest za pomoca klasycznego pytania o zaufanie: ,jak sądzisz, czy większości ludzi można ufać?", te zaś nie zawsze uznać można za wiarygodny miernik kapitału społecznego ${ }^{5}$. Aspekt ten jest przedmiotem analizy niniejszej pracy.

Używanie wskaźnika „zaufanie” bazującego na badaniach sondażowych może fałszywie wpływać na wnioski, co do oceny zasobów kapitału społecznego i jego związków z wynikami ekonomicznymi, czego przykładem są wyniki badań Martina Raisera ${ }^{6}$, pokazujące, że wzrost gospodarczy w krajach Europy Wschodniej nie ma związku z zaufaniem, ale ma związek z aktywnością społeczna.

Niniejszy artykuł ma na celu weryfikację tezy o niskim zaufaniu Polaków oraz ocenę - związanej z tym zaufaniem - wiarygodności. Cel ten osiagnięty może być dzięki porównaniu wyników badań eksperymentalnych w wymiarze międzynarodowym.

Przesłanką podjęcia się przedstawionego zadania badawczego są wyniki badań porównawczych na temat zaufania pochodzących z sondaży i badań eksperymentalnych. Edward E. Glaeser z zespołem ${ }^{7}$ oraz Sergio G. Lazzarini ${ }^{8}$ pokazali, że odpowiedzi na pytanie WVS nie sa skorelowane z przekazami graczy w grze „zaufanie” (ang. trust game - TG), choć są skorelowane z przekazami graczy $B$, czyli miarą wiarygodności ${ }^{9}$. Do podobnych wniosków doszli także Nava Ashraf z zespołem ${ }^{10}$, John Ermish z zespołem ${ }^{11}$, Hakan Holm i Paul Nysted ${ }^{12}$, Olaf Johanson ${ }^{13}$. Do innych wyników doszli natomiast Ernst Fehr z zespołem ${ }^{14}$

${ }^{5}$ A. S. Miller, T. Mitamura, Are surveys on trust trustworthy?, „Social Psychology Quarterly”, 66(1), 2003, s. 62-70; P. Teisseyre, Ład społeczny bez zaufania? Teorie socjologiczne wobec hipotezy o niedostatkach zaufania, [w:] Nowe rzeczywistości społeczne, nowe teorie socjologiczne. Dyskusje i interpretacje, red. M. Gdula, A. Grzymała-Kazłowska, R. Włoch, Scholar, Warszawa 2012, s. 135.

${ }^{6}$ M. Raiser et al., Social Capital in Transition..., op. cit.

${ }^{7}$ E. L. Glaeser et al., Measuring trust, „The Quarterly Journal of Economics” 115(3), 2000, s. 811-846.

${ }^{8}$ S. G. Lazzarini, R. Madalozzo, R. \& S. Artes, Measuring Trust: An Experiment in Brazil, Insper Working Paper, Insper Working Paper, Insper Instituto de Ensino e Pesquisa, październik 2004, http://econpapers.repec.org/paper/ibmibmecp/wpe_5f42.htm.

${ }^{9}$ Opis zasad gry znajduje się w dalszej części pracy.

${ }^{10}$ N. Ashraf, I. Bohnet, N. Piankov, Decomposing trust and trustworthiness, „Experimental Economics" 9(3), 2006, s. 193-208.

${ }^{11}$ J. Ermisch et al., Measuring people's trust, „Journal of the Royal Statistical Society: Series A (Statistics in Society)" 172(4), 2009, s. 749-769.

${ }^{12} \mathrm{H}$. Holm, P. Nystedt, Trust in surveys and games - A methodological contribution on the influence of money and location, „Journal of Economic Psychology” 29(4), 2008, s. 522-542.

${ }^{13}$ O. Johansson-Stenman, M. Mahmud, P. Martinsson, Trust, trust games and stated trust: Evidence from rural Bangladesh, „Journal of Economic Behavior \& Organization” 95, 2013, s. 286-298.

${ }^{14}$ E. Fehr et al., A Nationwide Laboratory Examining Trust and Trustworthiness by Integrating Behavioural Experiments into Representative Surveys, SSRN Scholarly Paper, Social Science Research Network, Rochester, NY kwiecień 1, 2003, http://papers.ssrn.com/abstract=413204. 
oraz Charles Bellemare i Sabine Kroeger ${ }^{15}$, a także Xiangdong Qin z zespołem ${ }^{16}$. Wyniki badań E. Fehra wskazuja, że odpowiedzi na pytania o zaufanie sa skorelowane z przekazami graczy $A$. Z kolei Håkon Holm i Anders Danielson ${ }^{17}$ znaleźli związki, analizując dane dla Szwecji, i ich brak dla Tanzanii.

\section{ZAUFANIE I WIARYGODNOŚĆ}

Zaufanie - według Piotra Sztompki ${ }^{18}$ - to rodzaj zakładu, który robimy w ciemno, choć można je rozumieć także jako wyrozumowana kalkulację ${ }^{19}$. Zgodnie z definicją Diego Gambetty ${ }^{20}$, jeśli ufamy komuś, to uważamy, że prawdopodobieństwo tego, że osoba ta będzie zachowywać się dla nas korzystnie, jest wystarczająco wysokie, by rozważyć zaangażowanie we współpracę z ta osoba. Według Harveya S. Jamesa ${ }^{21}$, jeśli $A$ ufa $B$, oznacza to, iż $A$ oczekuje, że $B$ nie wykorzysta słabości $A$, które $A$ wywołał, angażując się w zdarzenie.

Zaufanie według P. Sztompki jest zakładem podejmowanym na temat niepewnych, przyszłych działań innych ludzi. Na tak rozumiane zaufanie składają się dwa elementy: przekonania i ich wyrażenie w praktyce ${ }^{22}$. W kontekście kapitału społecznego najistotniejsze jest zaufanie uogólnione, czyli przyjmowane a priori założenie o wiarygodności nieznajomych, obcych, wszystkich ludzi ${ }^{23}$. Wiarygodność jest nierozerwalnie związana z zaufaniem, jest jednym z jej filarów. Tam gdzie ludzie są wiarygodni, łatwiej o zaufanie. Według Russella Hardina ${ }^{24}$ istnieją trzy różne koncepcje zaufania i wszystkie odnoszą się do pojęcia wiarygodności. Hardin twierdzi nawet, że dotyczą one przede wszystkim wiarygodności, a tylko pośrednio zaufania.

Zaufanie i wiarygodność są o tyle istotne (w kontekście badań nad kapitałem społecznym), że umożliwiają współpracę dla wzajemnych korzyści. To właśnie kooperacja jest punktem wyjścia i najważniejszym zagadnieniem. Zaufanie jest jednym z uzasadnień podejmowania ryzykownej współ-

${ }_{15}$ C. Bellemare, S. Kröger, On representative social capital, „European Economic Review” 51(1), 2007, s. 183-202.

${ }^{16}$ X. Qin, J. Shen, X. Meng, Group-based trust, trustworthiness and voluntary cooperation: Evidence from experimental and survey data in China, „The Journal of Socio-Economics” 40(4), 2011, s. 356-363.

${ }^{17}$ H. J. Holm, A. Danielson, Tropic trust versus Nordic trust: experimental evidence from Tanzania and Sweden, „The Economic Journal” 115(503), 2005, s. 505-532.

${ }_{18}$ P. Sztompka, Zaufanie: fundament społeczeństwa, Znak, Kraków 2007.

${ }_{19}$ J. S. Coleman, Foundations of Social Theory, Harvard University Press, Cambrigde, MA, 1990.

${ }^{20}$ D. Gambetta, Can we trust trust, w: D. Gambetta (ed.), Trust: Making and Breaking Cooperative Relations, Department of Sociology, University of Oxford 2000, t. 2000, electronic edition, s. 213-237, http://www.loa.istc.cnr.it/mostro/files/gambetta-conclusion_on_trust.pdf [dostęp: 12.12.2016].

${ }^{21} \mathrm{H}$. S. James Jr., The trust paradox: a survey of economic inquiries into the nature of trust and trustworthiness, „Journal of Economic Behavior \& Organization” 47(3), 2002, s. 291-307.

${ }^{22}$ P. Sztompka, op. cit., s. 69-71.

${ }^{23}$ Ibidem, s. 148.

${ }^{24}$ R. Hardin, Zaufanie, Wydawnictwo Sic!, Warszawa 2009, s. 24-25. 
pracy, wiarygodność (trustworthiness), jest także jednym z argumentów, dla których takie ryzyko może się opłacać ${ }^{25}$.

Zaufanie jest komponentem ${ }^{26}$ wielu definicji kapitału społecznego. James Coleman definiuje kapitał społeczny jako „cechy charakterystyczne życia społecznego - sieci, normy i zaufanie - które ułatwiaja współpracę i koordynację działań ludzi dla wspólnego dobra ${ }^{27}$. Według Robert Putnama kapitał społeczny „odnosi się [...] do takich cech społeczeństwa jak zaufanie, normy i powiązania, które moga zwiększyć sprawność społeczeństwa, ułatwiając skoordynowane działania"28. Skutkiem tego jest to, że jedną z częściej analizowanych miar kapitału społecznego jest uogólnione zaufanie.

\section{ZASTOSOWANA METODA BADAWCZA}

W opracowaniu bazowano na wynikach badań przeprowadzanych z wykorzystaniem metody eksperymentu związanego z teorią gier (metoda ekonomii eksperymentalnej). Wyniki badań ekonomii eksperymentalnej, rozwijanej od lat pięćdziesiątych XX w., wskazują często, że założenie o egoistycznym charakterze jednostek nie potwierdza się. Jednostki nie sa motywowane jedynie chęcią zysku, ale także wykazują altruizm, normy wzajemności, zaufanie, niechęć do nadmiernych dysproporcji dochodowych czy poczucie niesprawiedliwości. Eksperyment pozwala na ujawnienie się preferencji graczy, czego badacze często nie są w stanie zaobserwować w wyniku stosowania tradycyjnych metod: sondażu, ankiety, wywiadu. Metoda eksperymentu umożliwia obserwację zachowań jednostek w różnych sytuacjach, a zapewnienie realizmu psychologicznego (uzyskiwanego m.in. dzięki rzeczywistym nagrodom (i/lub karom) pozwala na wyciaganie bardziej wiarygodnych wniosków.

Badania autorskie, wyniki których wykorzystano w pracy do przeprowadzenia (metaanalizy), przeprowadzono w okresie IV-VI 2014 r. na próbie 1540 osób - studentów publicznych uczelni wyższych zlokalizowanych w 16 miastach Polski. W każdym z regionów przebadano 88-100 osób ${ }^{29}$. Badane osoby

\footnotetext{
${ }^{25}$ R. Hardin, Trust and Trustworthiness, Russell Sage Foundation Publications, New York 2002, s. 173.

${ }^{26}$ Choć istnieje problem z określeniem relacji pomiędzy zaufaniem a kapitałem społecznym. Niektórzy utożsamiaja go z kapitałem społecznym, jak F. Fukuyama, inni traktuja jako źródło i zasadniczy składnik tego kapitału, jak robi to R. Putnam, jeszcze inni jako jedną z form (Coleman).

${ }_{27}$ J. S. Coleman, Social capital in the creation of human capital, „American Journal of Sociology" 94, 1988, s. S95-S120.

${ }^{28}$ R. D. Putnam, Demokracja w działaniu: Tradycje obywatelskie we wspótczesnych Włoszech, Znak, Kraków 1995, s. 258.

${ }^{29}$ Więcej na temat organizacji badania: U. Markowska-Przybyła, D. Ramsey, A game theoretical study of generalised trust and reciprocation in Poland: I. Theory and experimental design, „Operations Research and Decisions” 2014, nr 3, s. 59-77; U. Markowska-Przybyła, D. Ramsey, A game theoretical study of generalised trust and reciprocation in Poland: II. A description of the study group, „Operations Research and Decisions” 2015, nr 2, s. 51-73.
} 
uczestniczyły w trzech grach (eksperymentach) oraz w badaniu ankietowym. Zastosowano trzy klasyczne gry: grę „zaufanie” (trust game, TG), grę w „dobro publiczne” (public good game, PGG) oraz grę „ultimatum” (ultimatum game, UG). W niniejszym opracowaniu omówione zostały wyniki eksperymentu ,zaufanie".

W grze trust game zaproponowanej przez Joyce Berg, Johna Dickhauta i Kevina McCabe'go ${ }^{30}$, zwanej też investment game bierze udział dwóch graczy (najczęściej anonimowych). Jeden z graczy $(A)$ dysponuje pewną kwota pieniędzy $(X)$, część tej kwoty, a nawet całość może przekazać (zainwestować) - według własnego uznania drugiemu z graczy $(B)$, jest to kwota $(Y)$. Kwota $Y$, zanim trafi do drugiego z graczy (gracza $B$ ), jest mnożona przez czynnik $\lambda$ większy niż 1, zazwyczaj 2 lub 3. Wiedza o tym oboje z graczy. Następnie drugi gracz $(B)$ decyduje (w warunkach niezależności od pierwszego gracza), czy przekazać z powrotem jakąś część otrzymanej kwoty $\lambda Y$. Gra trust game pozwala na badanie zaufania (udział przekazanej kwoty przez gracza $A$ ) oraz na badanie wiarygodności (solidności, godności zaufania) trustworthiness, która jest frakcja $\lambda Y$ zwracana pierwszemu graczowi

Zgodnie z założeniem racjonalności postępowania jednostek przyjmowanym w ekonomii, gracz $A$ nie powinien nic przekazać drugiemu graczowi (gdyż powinien założyć, że gracz $B$ postapi racjonalnie i nie zwróci mu nic z przekazanej kwoty). Drugi gracz nie powinien nic zwrócić, w przypadku gdy otrzyma jakąkolwiek kwotę. Równowaga Nasha ma miejsce wówczas, gdy strategia każdego z graczy jest optymalna, bioracc pod uwagę wybór innych graczy za ustalony. W tym przypadku zachodzi ona wówczas, gdy pierwszy gracz nic nie przekazuje drugiemu graczowi (pierwszy z graczy przyjmuje założenie, że drugi gracz $(B)$ nie zwróci mu nic z przekazanej kwoty). Jednak w praktyce badawczej okazuje się, że gracze nie postępują zgodnie z założeniem racjonalności zachowań. Wytłumaczeniem tego może być to, że gracz $A$ spodziewa się innego zachowania po graczu $B$, niż to wynikajace z racjonalności ekonomicznej, kieruje się zaufaniem, czyli założeniem, że gracz $B$ zachowa się w sposób dla niego (tj. dla gracza $A$ ) korzystny, ryzykujac osobistą stratę. Graczem $A$ kieruje także awersja do nierówności, która powoduje, że niektórzy gracze, nawet nieufni przekazują drobna część posiadanej kwoty ${ }^{31}$. W praktyce także drugi gracz nie zachowuje się racjonalnie z punktu widzenia ekonomii i przekazuje część kwoty z powrotem graczowi $A$. U podstaw takiego zachowania leży najprawdopodobniej norma wzajemności, gracz $B$ przekazuje część otrzymanej kwoty jako odpowiedź na okazane mu zaufanie.

W przeprowadzonych badaniach gracz $A$ miał do dyspozycji 10 zł, kwota przekazywana graczowi $B$ była mnożona przez 3. Połowa graczy odgrywała rolę $A$, druga - rolę $B$. Ponieważ gracze pozostawali anonimowi dla siebie zarówno podczas gry, jak i po jej zakończeniu, zaufanie okazane przez gracza $A$ w postaci przekazu utożsamione zostało z zaufaniem uogólniomym.

${ }^{30}$ J. Berg, J. Dickhaut, K. McCabe, Trust, reciprocity, and social history, „Games and Economic Behavior" 10(1), 1995, s. 122-142.

${ }^{31}$ U. Markowska-Przybyła, D. Ramsey, The association between social capital and membership of organisations amongst Polish students, „Economics and Sociology” 9(4), 2016. 
Przeprowadzone badania eksperymentalne poszerzono o badania ankietowe. Badanym studentom zadano pytania o zaufanie:

- klasyczne pytanie stosowane w wielu międzynarodowych badaniach nad zaufaniem: „Jak sądzisz, czy większości ludzi można ufać?”, z możliwymi wariantami odpowiedzi: tak, raczej tak, nie wiem, raczej nie, nie, oraz

- zgodnie z tym, że zaufanie składa się z dwóch elementów: przekonań i zachowań, zapytano studentów o przekonania: „Jak myślisz, jaką część (ile procent) posiadanej przez niego kwoty zwrócił Ci gracz $B$ w grze nr 2 ?" ${ }^{32}$.

\section{ZAUFANIE I WIARYGODNOŚĆ W ŚWIETLE BADAŃ EKSPERYMENTALNYCH}

W grze ,zaufanie” obserwacja zachowań graczy A (sender, trustor) pozwala na identyfikację ich zaufania (trust) ${ }^{33}$, w stosunku do drugiego anonimowego gracza, a zachowanie graczy $B$ (receiver, trustee) świadczy o ich wiarygodności (trustworthiness). Graczem $A$, oprócz zaufania, kieruja także inne motywy, jak skłonność do ryzyka czy altruizm. Podobnie decyzje gracza $B$ motywowane moga być także innymi czynnikami, w tym ich altruizmem i stosunkiem do nierówności. Odsetek przekazanej kwoty, która mają do dyspozycji gracze, zależy także - jak wskazują niektóre badania od innych czynników związanych z konstrukcja gry:

- wysokości kwoty jaka jest rozgrywana ${ }^{34}$;

- od mnożnika - jest on wyższy od 1 (zwykle 3), gdyż taka konstrukcja powoduje, że zaufanie generuje korzyści ekonomiczne. Im wyższy mnożnik, tym wynagrodzenie to jest większe i wzrasta prawdopodobieństwo, że gracz $A$ przekaże wyższe kwoty;

- anonimowości;

- od statusu graczy, tj. czy są studentami, jak to ma najczęściej miejsce, czy nie;

${ }^{32}$ Wyniki badań na ten temat można odnaleźć w pracy: U. Markowska-Przybyła, D. Ramsey, Zaufanie jako miara kapitału społecznego - dane deklarowane a obserwowane, „Studia i Prace WNEiZ US" 44/2, 2016, s. 223-236.

${ }^{33}$ Przedstawiona gra jest jednym z częściej (o ile nie najczęściej) wybieranym sposobem pomiaru obserwowanego zaufania, aczkolwiek niektóre prace wskazują na jej ograniczenia, argumentując, że przekazywana kwota mierzy także poziom altruizmu J. C. Cox, How to identify trust and reciprocity, „Games and Economic Behavior” 46(2), 2004, s. 260-281: „experiments with the triadic design do discriminate between transfers resulting from trust or reciprocity and transfers resulting from other-regarding preferences that are not conditional on the behavior of others. Decomposing trust from altruism and reciprocity from altruism or inequality aversion is critical to obtaining empirical information that can guide the process of constructing models that can increase the empirical validity of game theory", DOI: 10.1016/S0899-825603, czy awersję do zdrady I. Bohnet et al., Betrayal aversion: evidence from Brazil, China, Oman, Switzerland, Turkey, and the United States, „The American Economic Review” 98(1), 2008, s. 294-310.

${ }_{34}$ J. Carpenter, E. Verhoogen, S. Burks, The effect of stakes in distribution experiments, „Economics Letters” 86(3), 2005, s. 393-398; S. D. Levitt, J. A. List, What do laboratory experiments tell us about the real world?, „Journal of Economic Perspectives” 21(2), 2006, s. 153-174. 
- od tego, czy gracz $B$ jest wynagradzany niezależnie od decyzji gracza $A$;

- od tego, czy gracze odgrywaja obie role czy tylko jedna;

- od tego, czy wynagrodzenie graczy jest pewne, czy obarczone dodatkowym ryzykiem, jest tak wówczas, gdy wypłaty graczy są losowe;

- od tego, czy partner w grze jest prawdziwym graczem (człowiekiem) czy komputerem.

Szeroko zakrojone badania porównujace wyniki gier „zaufanie” przeprowadzili Noel D. Johnson i Alexandra A. Mislin ${ }^{35}$. Przeanalizowano w nich łącznie 162 badania przeprowadzone w 35 krajach, które objęły 23924 badanych $^{36}$. W przeprowadzonej analizie porównawczej nie wystapiły badania obejmujace Polskę. Niniejszy artykuł może być wkładem w dotychczasowy stan wiedzy o zaufaniu i wiarygodności polskich graczy, tym bardziej że założenia gry „zaufanie" wpisują się w kryteria porównanych przez Johnsona i Mislin badań ${ }^{37}$.

Przeciętny przekaz graczy $A$, interpretowany jako poziom zaufania, w 161 badaniach przeprowadzonych w różnych częściach świata wynosi 50,2\% posiadanej kwoty, choć wartość ta wykazuje dużą zmienność - waha się od $22,4 \%$ do $88,5 \%$. Na poziomie kontynentów, najwyższe przekazy zaobserwowano w Europie (53,7\%), Ameryce Północnej (51,7\%), najniższe w Afryce (45,6\%) i Ameryce Południowej (45,8\%). Przeciętny zwrot gracza $B$ (jako procent otrzymanej kwoty), który utożsamiany jest z poziomem wiarygodności, wynosił w przeprowadzonych 137 badaniach 37,2\% i wahał się między 10,8\% a 81,2\%. Najwyższy był w Azji (46\%), najniższy w Afryce (31,9\%).

Przedstawiony przez N. Johnsona i A. Mislin katalog 162 przeanalizowanych badań zawężono w niniejszej pracy do 67, które są podobne w swej konstrukcji do gry przeprowadzonej przez autorów niniejszej pracy. Wyeliminowano z pierwotnego zbioru 162 badań te, w których:

- graczem - partnerem w grze, nie jest człowiek, tylko komputer, a badani o tym wiedzą: badania wskazuja, że ludzie podejmują wówczas zróżnicowane decyzje i przekazują mniej pieniędzy, gdy wchodzą w interakcję z kompute$\mathrm{rem}^{38}$

${ }^{35}$ N. D. Johnson, A. A. Mislin, Trust games: a meta-analysis, „Journal of Economic Psychology" 32(5), 2011, s. 865-889.

${ }^{36}$ Zastosowane przez Johnsona i Mislin kryteria wyszukiwania i selekcji prac poddanych analizie wytypowały 130 prac badawczych dostarczających informacji o 162 przeprowadzonych grach „trust” i 161 obserwacjach dotyczących średniego przekazu gracza $A$ oraz o 137 obserwacjach dotyczących średniego zwrotu gracza $B$. Niektóre prace dostarczały informacji o więcej niż jednej grze „zaufanie”, np. dotyczyły zastosowań tej gry w różnych krajach. Jedna z prac dostarczyła danych o zwrocie gracza $B$, jednak zastosowane kryteria selekcji nie pozwoliły na wykorzystanie danych o kwocie przekazu gracza $A$.

${ }^{37} \mathrm{~W}$ porównaniu wzięto pod uwagę gry zbliżone w założeniach do gry zaproponowanej przez Berga i zespół: J. Berg, J. Dickhaut, K. McCabe, op. cit., np. wykluczono gry o binarnym charakterze, która wymusza na graczu wybór między jedynie dwoma opcjami (czyli gdy np. gracz $A$ może albo całą sumę graczowi $B$ przekazać, albo nic mu nie przekazać), gry z uczestnikami poniżej 17 roku życia.

${ }^{38}$ W. P. Bottom et al., Building a Pathway to Cooperation: Negotiation and Social Exchange between Principal and Agent, SSRN Scholarly Paper, Social Science Research Network, Rochester, NY 2006, http://papers.ssrn.com/abstract=602074; A. G. Sanfey et al., The neural basis of economic decision-making in the Ultimatum Game, „Science (New York, N.Y.)” 300(5626), 2003, s. $1755-1758$. 
- brakuje anonimowości: gdy jej brakuje, do głosu dochodzą inne motywy podejmowanych decyzji, jak obawa o reputację, obawa o karę, odwzajemnianie przeszłych zachowań graczy;

- graczami nie sa studenci: badania przeprowadzane z udziałem innych grup niż studenci przynoszą odmienne wyniki, np. wyższy wiek badanych wiąże się z niższym zaufaniem ${ }^{39}$;

- gracze odgrywają obie role: w niektórych grach gracze odgrywaja rolę $A$ i rolę $B$ z różnymi partnerami, co pozwala na zebranie większej ilości obserwacji z badania. Badania Stephena Burksa i jego zespołu ${ }^{40}$ wskazuja, że osoby, które odgrywają obie role i są tego świadome, przekazują mniej pieniędzy jako gracz $A$;

- wypłaty mają losowy, nie zaś gwarantowany, charakter: ma to na celu obniżenie kosztów badania, jednak badania Williama P. Bottoma ${ }^{41}$ wskazuja, że wprowadza do dodatkowy element ryzyka do gry, co może obniżać wysokość przekazywanych środków;

- mnożnik jest różny od 3.

W przeprowadzonej przez N. Johnsona i A. Mislin metaanalizie czynniki te okazywały się także istotnie statystycznie wpływać na wysokość przekazów graczy.

Tabela 1 przedstawia wyniki przeprowadzonej analizy porównawczej wysokości przekazów graczy $A$ (zaufanie) i graczy $B$ (wiarygodność) w 67 porównywanych badaniach oraz wyniki badań autorskich.

Tabela 1

Zaufanie i wiarygodność według krajów w świetle badań eksperymentalnych (trust game)

\begin{tabular}{|l|c|c|c|c|}
\hline \multicolumn{1}{|c|}{ Kraj/region } & $\begin{array}{c}\text { Liczba } \\
\text { prac } \\
\text { badawczych }\end{array}$ & $\begin{array}{c}\text { Wielkośc } \\
\text { próby } \\
\text { badawczej }\end{array}$ & $\begin{array}{c}\text { Przeciętny } \\
\text { przekaz } \\
\text { gracza } \boldsymbol{A}\end{array}$ & $\begin{array}{c}\text { Przeciętny } \\
\text { zwrot gracza } \boldsymbol{B} \\
\text { (wroporcji } \\
\text { do otrzymanej } \\
\text { kwoty) }\end{array}$ \\
\hline Afryka Południowa & 1 & 308 & 0,33 & 0,23 \\
\hline Francja & 4 & 197 & 0,36 & 0,35 \\
\hline Kenia & 1 & 64 & 0,42 & 0,51 \\
\hline Włochy & 4 & 509 & 0,42 & 0,34 \\
\hline Polska & 1 & 1540 & 0,48 & 0,34 \\
\hline Kolumbia & 1 & 160 & 0,50 & 0,39 \\
\hline Szwecja & 1 & 110 & 0,51 & 0,35 \\
\hline Tanzania & 11 & 200 & 0,53 & 0,37 \\
\hline Niemcy & 1 & 817 & 0,54 & 0,36 \\
\hline Wielka Brytania & & 96 & 0,56 & 0,27 \\
\hline
\end{tabular}

${ }^{39}$ C. Bellemare, S. Kröger, op. cit.; E. Fehr et al., op. cit.

${ }^{40}$ S. Burks, J. Carpenter, E. Verhoogen, Playing both roles in the trust game, „Journal of Economic Behavior \& Organization" 51(2), 2003, s. 195-216.

${ }^{41}$ W. P. Bottom, Negotiator risk: sources of uncertainty and the impact of reference points on negotiated agreements, „Organizational Behavior and Human Decision Processes” 76(2), 1998, s. 89-112. 


\begin{tabular}{|l|c|c|c|c|}
\hline Bułgaria & 2 & 62 & 0,57 & 0,39 \\
\hline Stany Zjednoczone & 25 & 1528 & 0,59 & 0,37 \\
\hline Chiny & 2 & 120 & 0,62 & 0,34 \\
\hline Kanada & 4 & 392 & 0,62 & 0,31 \\
\hline Austria & 4 & 404 & 0,65 & 0,35 \\
\hline Nowa Zelandia & 1 & 41 & 0,66 & - \\
\hline Korea Południowa & 1 & 52 & 0,67 & 0,29 \\
\hline Japonia & 1 & 44 & 0,69 & 0,32 \\
\hline Holandia & 1 & 60 & 0,70 & 0,44 \\
\hline
\end{tabular}

Źródło: obliczenia własne na podstawie N. D. Johnson, A. Mislin, Trust games: a meta-analysis, „Journal of Economic Psychology” 32(5), 2011, s. 865-889, oraz badań własnych.

Średni przekaz pieniężny gracza $A$ w Polsce wyniósł 47,8\% posiadanej kwoty. W porównywanych krajach udział ten niższy był jedynie w krajach Afryki oraz Francji i Włoch. Gracze większości krajów Europy przekazywali przeciętnie wyższe kwoty, przekazy te wyższe były także w krajach Azji i Stanów Zjednoczonych.

Mimo że wielkość prób badawczych w większości krajów pozostawia wiele do życzenia, to trudno w tym przypadku o obalenie tezy o niskim zaufaniu Polaków. Wyniki badań sondażowych, chociaż często nie korelują z obserwowanym zachowaniem na poziomie jednostkowym (na co wskazuja badania przytoczone we wstępie), wydają się korelować na poziomie zagregowanym, co potwierdzają badania N. Johnsona i A. Mislin ${ }^{42}$, w których badano wiarygodność pytania o zaufanie używanego w badaniach World Values Survey. Przeprowadzona przez Johnsona i Mislin analiza wskazała na silną korelację pomiędzy wynikami laboratoryjnymi (gra trust) a wynikami sondażowymi agregowanymi na poziomie krajów.

Niskiemu zaufaniu polskich studentów towarzyszy stosunkowo niska wiarygodność. W przeprowadzonych przez autorów badaniach gracze $B$ przekazywali z powrotem średnio 33,55\% otrzymanej kwoty, co w świetle konstrukcji gry stanowi równowartość przekazu gracza $A$. Gracze $B$ (przeciętnie) nie dzielili się z graczem $A$ zyskiem z inwestycji. Niższy zwrot charakteryzował graczy Afryki południowej, Korei Południowej, Wielkiej Brytanii, Kanady i Japonii. W pozostałych krajach zwrot ten był wyższy.

\section{METAANALIZA}

W celu przeprowadzenia głębszej analizy rozważono wszystkie badania opisane w pracy N. Johnsona i A. Mislin (2011), które spełniły jednocześnie następujące warunki: a) oboje gracze byli ludźmi, b) gracze byli anonimowi, c) mnożnik był równy 3 . Pozostałe różnice konstrukcyjne zostały uwzględnio-

${ }^{42}$ N. D. Johnson, A. Mislin, How Much Should We Trust the World Values Survey Trust Question?, SSRN Scholarly Paper, Social Science Research Network, Rochester, NY, October 2, 2011, http://papers.ssrn.com/abstract=1937309. 
ne z przeprowadzonej poniżej analizie. Uzyskano w ten sposób 115 badań, do których dołączono w analizie badania autorskie. Należy podkreślić, że badania autorskie miały największą liczbę uczestników (1540), drugie z kolei badania, ze względu na liczbę uczestników, odbyły się w trzech krajach Europy Zachodniej (851 studentów ${ }^{43}$ ). Liczbę uczestników oraz miejsce tych badań opisano w tabeli 2 .

Tabela 2

Opis badań przyjętych do metaanalizy (nie uwzględnia badań autorów)

\begin{tabular}{|c|c|c|}
\hline Rejon & Liczba badań & Całkowita liczba uczestników \\
\hline Europa Zachodnia & 42 & 5035 \\
\hline Europa Centralna/Wschodnia & 5 & 894 \\
\hline Ameryka Północna & 39 & 4109 \\
\hline Ameryka Centralna/Południowa & 3 & 1106 \\
\hline Azja & 10 & 1453 \\
\hline Afryka & 13 & 1965 \\
\hline Oceania & 3 & 278 \\
\hline Ogółem & 115 & 14840 \\
\hline
\end{tabular}

Źródło: obliczenia własne na podstawie N. D. Johnson, A. Mislin, How Much Should We Trust the World Values Survey Trust Question?, SSRN Scholarly Paper, Social Science Research Network, Rochester, NY, October 2, 2011.

W metaanalizie przyjęto następujące zmienne wyjaśniające:

- Rejon został kodowany za pomoca 6 zmiennych binarnych, $X_{1}-X_{6}$, gdzie:

$\circ X_{1}=1$, gdy badania odbyły się w Europie Centralnej/Wschodniej, inaczej $X_{1}=0$,

○ $X_{2}=1$, gdy badania odbyły się w Ameryce Północnej, inaczej $X_{2}=0$,

$\circ X_{3}=1$, gdy badania odbyły się w Ameryce Centralnej/Południowej, inaczej $X_{3}=0$,

$\circ X_{4}=1$, gdy badania odbyły się w Azji, inaczej $X_{4}=0$,

$\circ X_{5}=1$, gdy badania odbyły się w Afryce, inaczej $X_{5}=0$,

$\circ X_{6}=1$, gdy badania odbyły się w Oceanii, inaczej $X_{6}=0$.

○ Gdy wszystkie te zmienne były równe 0 , oznacza to, że badania odbyły się w Europie Zachodniej. Wyniki z Europy Zachodniej potraktowane zostały jako podstawę do porównań z innymi rejonami z uwagi na to, że w Europie Zachodniej odbyło się najwięcej badań z największą liczbą uczestników. $\mathrm{W}$ dodatku pozwoliło to na wykonanie bezpośredniego porównania między krajami postkomunistycznymi a krajami Europy Zachodniej, które są im najbliższe kulturowo i geograficznie.

${ }^{43}$ M. Migheli, Is Participation to Voluntary Association Linked with Trust? Experimental Evidence from the Youth, SSRN Scholarly Paper, Social Science Research Network, Rochester, NY marzec 1, 2008, http://papers.ssrn.com/abstract=1117361. 
- Pod uwagę wzięto także następujące czynniki:

a) czy badania były „podwójnie ślepe” (double blind) (32 z 115, tj. 27,83\% badań);

b) czy obaj gracze mieli tę samą kwotę na początku gry (70 z 115, tj. 60,87\%);

c) czy wszyscy gracze byli studentami (91 z 115, tj. 79,13\%);

d) czy drugi gracz korzystał z podejścia strategicznego (czyli czy określił, ile pieniędzy oddałby przy każdym możliwym przelewie) (29 z 115, tj. 25,22\%);

e) czy obaj gracze odgrywali obie role (26 z 115, tj. 22,61\%);

f) czy tylko losowo wybrani gracze dostawali wypłaty (27 z 115, tj. 23,48\%);

g) czy gra była powtórzona (58 z 115, tj. 50,43\%).

Każdy z wymienionych czynników został oznaczony zmienną binarną w wymienionej wyżej kolejności od $X_{7}$ do $X_{13}$, tak że odpowiednia zmienna przyjęła wartość 1 , gdy odpowiedź na pytanie brzmi „tak”, inaczej przyjęła ona wartość 0 . W badaniach autorskich tylko odpowiedź na pytanie c) brzmi „tak”.

- Dodatkowo rozważona została kwota posiadana przez pierwszego gracza w dolarach według parytetu siły nabywczej, $X_{14}$.

Rozważono następujące zmienne zależne:

- $P_{1}$ - średnia proporcja pieniędzy przekazanych przez pierwszego gracza (jako proporcja kwoty posiadanej).

- $P_{2}$ - średnia proporcja pieniędzy zwróconych przez drugiego gracza (jako proporcja kwoty otrzymanej).

Wartości obu zmiennych należą do przedziału $(0,1)$, dlatego wykonujemy regresję logistyczna. Zmienne zależne w modelu regresji liniowej to $Y_{1}$ oraz $Y_{2}$, gdzie

$$
Y_{i}=\ln \frac{P_{i}}{1-P_{i}}, \text { gdzie } i=1,2 \text {. }
$$

Wynika z tego, że:

$$
P_{i}=\frac{e^{Y_{i}}}{1+e^{Y_{i}}}
$$

W pierwszej kolejności zbudowano model, który przewiduje proporcję kwoty przekazanej przez pierwszego gracza z wykorzystaniem metody najmniejszych kwadratów ważonych, gdzie każda obserwacja jest ważona przez liczbę uczestników w danych badaniach ${ }^{44}$. Wykorzystano regresję krokową za pomocą pakietu GRETL. W każdym kroku, wprowadzamy zmienną wyjaśniająca, która jest najbardziej skorelowana z zmienną zależną (biorąc pod uwagę wpływ zmiennych wyjaśniających znajdujących się już w modelu) aż znajdujemy model minimalizujacy indeks Akaike ${ }^{45}$.

${ }^{44}$ L. V. Hedges, I. Olkin, Statistical models for meta-analysis, „The Power of Statistical Tests in Meta-Analysis. Psychological Methods" 6(3), 1985, s. 203-217.

${ }^{45}$ Zob. H. Akaike, A new look at the statistical model identification, „IEEE Transactions on Automatic Control" 19(6), 1974, s. 716-723. 
W wyniku otrzymano model o postaci:

$$
Y_{1}=0,144205-0,462449 X_{12}+0,343384 X_{10}-0,409426 X_{5},
$$

gdzie:

$X_{12}=1$ oznacza, że tylko losowo wybrani gracze dostają wypłatę,

$X_{10}=1$ oznacza, że drugi gracz używa podejścia strategicznego oraz

$X_{5}=1$ oznacza, że badania odbyły się w Afryce.

Z modelu wynika, że gdy tylko losowo wybrani gracze dostaja pieniądze, pierwszy gracz przekazuje mniej $\left(X_{12}\right)$. Jest to logicznie uzasadnione, gdyż ogólnie ludzie maja awersję do ryzyka. Dla graczy otrzymujacych wypłaty losowo powstaje dodatkowe źródło ryzyka (pierwsze (wspólne dla wszystkich graczy) - że drugi gracz nic nie odda, a drugie (dodatkowe) - że losowy mechanizm nie przydzieli wypłaty pierwszemu graczowi). W takich przypadkach gracze wola mechanizm, gdzie istnieje tylko jedno źródło ryzyka, a nie dwa ${ }^{46} . \mathrm{Z}$ modelu wynika także, że pierwszy gracz przekazuje więcej, gdy drugi gracz korzysta z podejścia strategicznego (czyli określa, ile oddałby przy każdym możliwym przekazie, $\left.\left(X_{10}\right)\right)$. Może to oznaczać, że podejście to podkreśla poczucie, że w tej grze rozchodzi się o odwzajemnienie. Model wskazuje także, że Afrykańczycy przekazują mniej niż inni $\left(X_{5}\right)$.

W następnej kolejności zbudowano model, który przewiduje proporcję kwoty oddanej pierwszemu graczowi. Korzystając z metody zastosowanej w pierwszym modelu, otrzymano następujący wynik:

$$
Y_{2}=-0,85556-0,32555 X_{5}-0,17226 X_{9}+0,63769 P_{1}+0,28533 X_{4}+0,23975 X_{3} .
$$

Według tego modelu (2), Afrykańczycy $\left(X_{5}\right)$ w porównaniu do Europejczyków oddają mniej, a mieszkańcy Azji $\left(X_{4}\right)$ oraz Ameryki Południowej i Centralnej $\left(X_{3}\right)$ oddają więcej niż mieszkańcy Europy. Model też wskazuje, że studenci oddają mniej niż inni gracze (niestudenci) $\left(X_{9}\right)$, a także że proporcja pieniędzy oddanych rośnie względem wartości przekazu od pierwszego gracza (P1). Mieszkańcy Ameryki Północnej oraz Oceanii oddają taką samą proporcję, jak mieszkańcy Europy. Nie jest to wynik zadziwiający, wziąwszy pod uwagę, że kultury tych dwóch pierwszych regionów wywodziły się głównie z kultury Europy Zachodniej. Obecnie mieszkańcy tych trzech regionów tworza tzw. kulturę zachodnia.

Opierając się na powyższych modelach, porównano zachowanie polskich studentów do zachowania uczestników z innych badań. W tym celu przyjęto, że $P_{1}$ będzie estymatorem proporcji przekazanej, a $P_{2}$ będzie estymatorem proporcji oddanej, gdzie $\quad \hat{P}_{i}=\frac{e^{\hat{Y}_{i}}}{1+e^{\hat{Y}_{i}}}, \quad$ a $Y_{\mathrm{i}}$ otrzymujemy odpowiednio z modelu (1) lub (2).

Z równania (1) wynika, że $\widehat{Y}_{1}=0,144205 \Rightarrow \hat{P}_{1}=e^{0,144205} /\left(1+e^{0,144205}\right) \approx 0,536$. 
Oznacza to, że według przewidywań modelu polscy studenci (gracze A) przekazują średnio 53,6\% swoich pieniędzy. W naszej próbie przekazali mniej $(47,9 \%)$.

$\mathrm{Z}$ równania $(2)$, wynika, że $\hat{Y}_{2}=-0,85556-0,17226+0,637693 \times 0,479 \approx-0,72236$

$\Rightarrow \hat{P}_{1}=\frac{e^{-0,72236}}{1+e^{-0,72236}} \approx 0,32687$.

Model przewiduje zatem, że polscy studenci oddają średnio $32,687 \%$ pieniędzy, które dostali. W naszej próbie oddali nieznacznie więcej, tj. 33,356\%.

W następnym kroku zbudowano analogiczne modele uwzględniajace dane z Polski (Polska zaliczona została do grupy: Europa Centralna/Wschodnia). Model opisujaccy ma tę samą postać (estymatory współczynników tylko trochę się różnią od tych w modelu (2)).

Model opisujący ma natomiast postać:

$$
Y_{1}=-0,151326-0,463153 X_{12}+0,345950 X_{10}-0,416968 X_{5}-189265 X_{1}
$$

Ostatni wyraz w tym modelu wskazuje, że w roli gracza $A$ osoby z Europy Centralnej/Wschodniej przekazują mniejszą część pieniędzy niż ci z Europy Zachodniej. Z drugiej strony, korzystając z standardowego testu istotności współczynnik ten nie jest istotny nawet na poziomie istotności $10 \%(p=0,1347)$. Pozostałe współczynniki są istotne na poziomie istotności 1\%.

Opierając się na tych modelach, można stwierdzić, że pod względem proporcji pieniędzy oddanych przez gracza $B$, Polacy (oraz ogólnie mieszkańcy Europy Centralnej/Wschodniej) nie różnią od osób z kultury zachodniej (Oceania, Europa Zachodnia, Ameryka Północna). Wyniki z pozostałych regionów wskazują istotne różnice: Afrykańczycy oddają mniejszą proporcję, badani z Ameryki Centralnej/Południowej oraz Azji oddają większą proporcję niż ci z kultury zachodniej.

Biorąc pod uwagę proporcję pieniędzy przekazanych przez gracza $A$, istnieją słabe tylko dowody, że Polacy przekazują mniejszą część (czyli są mniej ufni) niż pozostali Europejczycy.

\section{DYSKUSJA I WNIOSKI}

Przedstawione badania wnoszą nową wiedzę o zachowaniach Polaków na tle innych narodowości w kwestii zaufania i wiarygodności. Wprawdzie dotyczą one jednej specyficznej populacji - studentów, to w świetle badań nad dziedziczeniem wartości, norm i przekonań ${ }^{47}$ uznano, że socjalizacja jest ważnym

${ }^{47}$ Np. G. Tabellini, Culture and institutions: economic development in the regions of Europe, „Journal of the European Economic Association” 8(4), 2010, s. 677-716; Y. Algan, P. Cahuc, Inherited trust and growth, „The American Economic Review” 100(5), 2010, s. 2060-2092; P. Sapienza, L. Zingales, L. Guiso, Does culture affect economic outcomes?, „Journal of Economic Perspectives” 20(2), 2006, s. 23-48; J. Brosig-Koch et al., Still different after all these years: solidarity behavior 
czynnikiem kapitału społecznego, a osoby te reprezentują kapitał społeczny krajów, w których zostali wychowani. Wnioskowanie o kapitale społecznym kraju na podstawie zachowań tylko określonej grupy osób wydaje się, że nie jest pozbawione sensu, aczkolwiek należy mieć świadomość charakteru próby badawczej. Badania sondażowe wskazują na bardzo niski poziom zaufania uogólnionego. Badania European Social Survey (ESS) wskazuja że pod względem ogólnego zaufania zajmujemy jedno z ostatnich miejsc wśród krajów objętych badaniem. W ostatniej edycji badania ESS (2014) 14,2\% deklarowało zaufanie do innych osób ${ }^{48}$, podczas gdy w Norwegii czy Finlandii prawie 40\% badanych. Także w porównaniu z innymi państwa Europy Środkowo-Wschodniej Polacy deklarują stosunkowo niskie zaufanie, jedynie w Bułgarii i Albanii jest ono niższe. W'́ród 35 państw poddawanych cyklicznie co dwa lata badaniu od 2002 tylko w pięciu z nich zaufanie to jest niższe. Badania ankietowe wskazują nam jednak jedynie na deklarację badanych, na ich przekonania, nie zaś na zachowanie, co jest - jak podkreśla P. Sztompka - istotnym elementem zaufania.

Badania eksperymentalne pozwalaja na uchwycenie elementu „zachowanie”. Wprawdzie dokonano tego tylko dla wybranej grupy, tj. studentów, a nie całego społeczeństwa, to możliwe jest wyciagnięcie pewnych wniosków.

Proste porównanie wyników gry „zaufanie” wskazuje na niski stopień zaufania polskich studentów na tle studentów innych narodowości. Jednak pogłębione badania (metaanaliza) nie wskazują na istotne różnice w porównaniu do państw Europy zachodniej, zwłaszcza w kwestii wiarygodności. Poziom zaufania jest wprawdzie niższy niż w Europie zachodniej, jednak nie jest on istotnie statystycznie niższy.

Możliwe jest, że deklarowane zaufanie Polaków nie koreluje z zaufaniem „okazanym”. Wcześniejsze badania autorów wskazują na bardzo słabe (choć istotne statystycznie) korelacje pomiędzy deklaracjami a obserwacjami w tej kwestii ${ }^{49}$.

dr Urszula Markowska-Przybyta

Uniwersytet Ekonomiczny we Wroctawiu

urszula.markowska-przybyla@ue.wroc.pl

dr hab. David M. Ramsey

Politechnika Wrocławska

david.ramsey@pwr.edu.pl

in East and West Germany, „Journal of Public Economics” 95(11-12), 2011, Special Issue: International Seminar for Public Economics on Normative Tax Theory, s. 1373-1376.

${ }_{48} \mathrm{Tj}$. odpowiedzi 7-10 na 10-stopniowej skali zaufania.

${ }^{49}$ U. Markowska-Przybyła, D. Ramsey, Zaufanie jako miara kapitału społecznego-dane deklarowane a obserwowane..., op. cit. 


\section{GENERALISED TRUST AND TRUSTWORTHINESS AMONGST POLISH STUDENTS IN COMPARISON WITH OTHER NATIONS}

\section{Sum mary}

This article presents the results of an experimental research carried out in Poland on selected aspects of social capital. These aspects were trust and trustworthiness. Our research was conducted on a total of 1540 students at universities in 16 Polish cities, capitals of 16 administrative regions, and was based on a commonly used experimental game termed the 'Trust Game'. These results were compared with the results of studies performed in many other countries all over the world. It has been found that with regard to the proportion of money returned by Player $B$ (a measure of trustworthiness), Poles (and more generally, those from Central and Eastern Europe) do not significantly differ from other countries belonging to Western culture (Oceania, Western Europe, North America). Based on the proportion of the money transferred by Player $A$ (a measure of generalised trust), there is only a weak indication that Poles are less trusting than other Europeans. 
